https://helda.helsinki.fi

\title{
In search of unity : a new politics of solidarity and action for confronting the crisis of global capitalism
}

\section{Gills, Barry}

2019-11-10

Gills , B \& Chase-Dunn , C 2019 , ' In search of unity : a new politics of solidarity and action for confronting the crisis of global capitalism ' , Globalizations , vol. 16 , no. 7 , pp. 967-972 . https://doi.org/10.1080/

http://hdl.handle.net/10138/306885

https://doi.org/10.1080/14747731.2019.1655889

publishedVersion

Downloaded from Helda, University of Helsinki institutional repository.

This is an electronic reprint of the original article.

This reprint may differ from the original in pagination and typographic detail.

Please cite the original version. 


\section{Globalizations}

\section{In search of unity: a new politics of solidarity and action for confronting the crisis of global capitalism}

\section{Barry Gills \& Christopher Chase-Dunn}

To cite this article: Barry Gills \& Christopher Chase-Dunn (2019) In search of unity: a new politics of solidarity and action for confronting the crisis of global capitalism, Globalizations, 16:7, 967-972, DOI: $10.1080 / 14747731.2019 .1655889$

To link to this article: https://doi.org/10.1080/14747731.2019.1655889

曲 Published online: 23 Aug 2019.

Submit your article to this journal $\widetilde{ }$

Џ Article views: 947

Q View related articles $\square$

View Crossmark data $\longleftarrow$ 


\title{
In search of unity: a new politics of solidarity and action for confronting the crisis of global capitalism
}

\author{
Barry Gills ${ }^{a}$ and Christopher Chase-Dunn ${ }^{b}$ \\ ${ }^{a}$ University of Helsinki, Finland; ' ${ }^{\mathrm{b}}$ University of California-Riverside, CA, USA
}

\begin{abstract}
This essay is an introduction to a Special Forum by critical scholar-activists responding to the late Samir Amin's call for the establishment of a new political vehicle that would be capable of uniting diverse progressive and revolutionary movements consisting of the workers and peoples of the whole world. The purpose of this vehicle would be to confront and radically transform a global capitalist order in deep crisis. The authors of these essays tend to agree that Amin was a profound contributor to the global justice movement, and to the reformulation of Marxism to address the evolution of global capitalism and imperialism that took place in the late twentieth and early twenty-first centuries. However, some are critical of Amin's stance. The essayists differ about whether they see Samir Amin's proposal for the establishment of a global party as a good or bad idea. Among those who think it is a good idea there are differences regarding the organizational nature and issue focus of the proposed organization. There are also different attitudes toward the institution of the nation-state and regarding the sources of progressive revolutionary political forces in the contemporary world. We briefly review the main issues under contention.
\end{abstract}

\section{KEYWORDS}

Global Left; World Social Forum; Samir Amin; fifth international; global political organization

Samir Amin, a leading scholar and co-founder of the world-systems tradition, died on August 12, 2018. Just before his death, he published, along with close allies, a call for 'workers and the people' to establish a 'fifth international' [https://www.pambazuka.org/global-south/letter-intentinaugural-meeting-international-workers-and-peoples] to coordinate support to progressive movements. To honor Samir Amin's invaluable contribution to world-systems scholarship, we are pleased to present readers with a selection of essays responding to Amin's final message for today's anti-systemic movements. This forum is being co-published between Globalizations [https://www. tandfonline.com/rglo], the Journal of World-Systems Research [http://jwsr.pitt.edu/ojs/index.php/ jwsr/issue/view/75] and Pambazuka News [https://www.pambazuka.org/]. Additional essays and commentary can be found in these outlets.

The time has come to unite the hundreds of struggles, campaigns, networks, movements and organizations that are combating the different ways transnational corporations (TNCs) are appropriating our destinies ... people's rights have been systematically violated, the Earth and its resources destroyed, pillaged and contaminated, and resistance criminalized, while corporations continue committing economic and ecological crimes with impunity ... to confront corporate power and the system that protects and benefits TNCs, it is urgent and necessary to give a systematic response. We need to unite our experiences 
and our struggles, learn collectively from our victories and our failures and share our analysis and strategies ...

'Call to International Action', www.stopcorporateimpunity.org

Samir Amin was a lifelong and indefatigable protagonist of the cause of socialism, independence and justice for peoples of the Global South. Like many earlier revolutionaries, he saw the Global North as a nexus of imperialism in which the movements of workers and peoples had been compromised by their favoured position in the modern world-system. Amin was an Egyptian economist who spent much of his early life in Paris, before moving to Dakar, Senegal where he directed the Third World Forum. He died on August 12, 2018 and there have been many tributes to the man and his work. ${ }^{1}$ Samir Amin was one of the principal founders of the world-system perspective that emerged in the 1970s as a prominent critique of modernization theory. His analysis provided a new focus on the hierarchical nature of the international economy. He argued the need for progressive movements and national regimes in the Global South to 'delink' from the chains of imperialism in order to establish more self-reliant and independent forms of economic and political development (Amin, 1990). He advocated a new polycentric world order to supersede the hegemony of the global North and the continued legacy of centuries of colonialism. Amin's version of the world-system perspective was more influenced by his Marxist perspective and less by the Braudelian school which was prominent in the work of Immanuel Wallerstein and his followers. Amin's extensive knowledge of the history of North Africa, especially the work of Ibn Khaldun, enabled him to theorize the comparison between the modern capitalist world-system and earlier 'tributary' systems (Amin, 1980a, 1991). He offered a widely influential early critique of Eurocentric world history (Amin, 1989). Amin (1980b) was a pioneer in the study of contemporary global class relations, a predecessor of the theorists of global capitalism who emerged in the 1990s, some of whom are contributors to this Special Forum.

In this brief introduction we cannot possibly fully review the extraordinary ouvre of Samir Amin. What we can do is indicate the present context of his urgent call for global action and unity and discuss the essays contributed here by critical scholar-activists ${ }^{2}$ addressing Samir's call for the establishment of a global organization to mobilize progressive social forces and people's movements into a new global struggle to move humanity towards a just, democratic and collectively rational global commonwealth (Amin, 2008). As we write, the global climate change crisis is accelerating and deepening, threatening increasing environmental and social calamity. Vast sums continue to be spent on the military apparatus, on wars and preparations for wars, including possible nuclear confrontation. Democratic political culture is perceived to be on the defensive globally, as the trend towards authoritarianism intensifies. Yet, there is also an upsurge in the spirit of resistance. Rebellion is in the air again, in places as diverse as Armenia, Sudan, Hong Kong, Russia and many more. A new popular mobilization to demand urgent action to arrest global warming is fast gaining momentum. We may conclude that we live in revolutionary times. It is a time for rebellion. A time for renewed struggle for radical transformation of the dominant global system.

This engagement with Amin's proposal is motivated by both long-standing conditions of global injustice and by a series of recent developments that suggest a greater need for urgency and solidarity. The World Social Forum process, though still holding promise, is seemingly in need of either reinvention or replacement. The Latin American Pink Tide has now entered a new phase of crises, wherein authoritarian and right-wing regimes are arising. Numerous right-wing, populist, nationalist and even neofascist movements and parties have emerged in Europe. The new radical progressive and anti austerity parties that emerged in Spain and Greece have been either defeated or obstructed 
by the neoliberal policies of the European banking system. Internationalist cosmopolitanism, in both neoliberal and progressive forms, is increasingly challenged by nationalist and populist movements. Some progressives have concluded that the large global demonstrations that were the template for the global justice movement in the 2000s are no longer a sufficient response. The search for new forms of organization and action to unite progressive and democratic forces throughout the world in order to effectively address mounting local, regional and global crises is now an ever more urgent concern.

Samir Amin was an active participant in the World Social Forum (WSF) process as recounted in several of the essays; including those by Teivo Teivainen and Patrick Bond. Critique of the perceived limitations of the WSF is a recurrent theme in the essays. The need to reinvent its process is argued by Alvarez and Chase Dunn, who offer a critical account of the limitations of horizontality and loose organizations. Patrick Bond highlights the gap between top-down intellectual formulations and manifestos and bottom-up strategic narratives, and criticizes the WSF for the lack of coherent ideology. He, and Bonn Juego point to the need to strengthen the connection between a new international as an organization and active social struggles and mass social movements. William Robinson offers a critical view of the refusal of the WSF to adopt a political programme and he advocates a new structure that includes both progressive political parties and social movements, to create a new model of transnational revolutionary struggle. Desai points to Amin's criticism of 'Proudonist economics and network politics' while calling for a renewed emphasis on anti- imperialist resistance and active pursuit of socialist economic reconstructions. Juego also stresses the limitations of the past network structure of both new social movements and the WSF. The systemic unity of capitalism should be recognized and the radical response needs to be one with global coordination amongst diverse social forces and forms of struggle in a 'continuous dialogue' and active coalition building.

Amin himself tried to influence the WSF to move away from the model of a discursive arena and evolve toward a more structured organization that would adopt consensual positions and undertake coordinated campaigns. The struggle between those in the leadership who wanted to maintain the WSF as an inclusive 'open space' for diverse social movements, and those like Amin and others who wanted to move in the direction of a more structured political organization reflected a strong current in the culture of the Global Left that emerged in the World Revolution of $1968 .{ }^{3}$ This tension has been described as one between horizontalism (loose networks of equals) and verticalism (hierarchical organizational command and control structures), discussed in the Alvarez and Chase Dunn essay. Amin and other proponents of greater organizational coherence have not advocated creating hierarchical control structures. As reviewed in the essay by Sahan Karatasli, the Global Left has alternated between more and less hierarchical forms of organization since the middle of the nineteenth century. The belief that communist parties are always internally undemocratic is a widely held myth, but the New Left critique of the Old Left and the demise of the Soviet Union has confirmed this belief in the minds of a majority of contemporary progressive activists. Any effort to found a capacious progressive global political organization must contend with this perception. These and related issues are analysed in historical and contemporary context by Boris Kagarlitsky. He argues that it was the defeat of the global left that stimulated rapid increases in corruption and in decay amongst the dominant capitalist classes; aggravating all the contradictions and problems the system faced. Kagarlitsky argues that it was the failures of both revolutionary and reformist alternatives to the rule of capital that have been the key factors affecting the decay of the bourgeois order.

The contributions to the forum diverge around whether they endorse or criticize Amin's proposal for a new international. Most of the contributors endorse the basic idea of the need for some type of new global umbrella organization that would unite diverse movements across global South and 
North and seek coalitions amongst diverse struggles. The imperative for creating a new form of global organization includes the threat posed by the accelerating global climate change crisis, increasing global inequality and concentration of wealth in oligarchic circles, and the imminent threat of rising nationalist, right wing populist and authoritarian movements and regimes. Mamdouh Habashi, a fellow Egyptian and close ally of Amin within the World Forum for Alternatives (which was founded by Samir Amin to bring together radicals and revolutionaries from across the globe) uses his essay to explain the reasons a new organization must be established and to outline a series of key questions concerning its aims and constitutional structures. ${ }^{4}$ Alvarez and Chase Dunn elaborate on the 'diagonal' model of transnational revolutionary organization, which aims to synthesize horizontality with verticalism and practice democratic collective decision-making.

The rise of twenty-first century forms of fascism is a threat acknowledged by many of the essays. Ferreia's essay points to the danger of populism and the dilution of class into a 'fascist mass'. He stresses the vital role of the proletariat in building a new international and a unitary articulation of a socialist transition. Robinson explicitly invokes the idea of constructing a broad anti-fascist front on transnational scale. Mestrum calls for a transition that combines social and environmental justice with a campaign against fascism, while Agozino insists on recognition of the links between racism, imperialism and patriarchy on world scale. Alvarez and Chase Dunn advocate naming the predations of the transnational corporate class and the neo-fascist and populist global Right as the enemy.

There are other important issues at play in the essays. Some authors contest the very idea of global organizing, claiming that the only sensible approach is to focus on the creation of local sustainable communities that can confront the problems of the Anthropocene (Leslie Sklair; Andrej Grubacic). These same authors see the state, as well as capitalism, as a necessarily repressive institution that must be abolished. Grubacic explains Abdullah Ocalan's reconceptualization of the nation as a diverse community of freely associating cooperators, challenging the more predominant existing versions of both nations and states. Amin, it should be noted, was a proponent of progressive nationalism and the use of state power by workers and farmers for purposes of mobilizing a more egalitarian and self-reliant political economy. While leftist global cosmopolitans are usually critics of nationalism and the nation-state as institutions, Amin contends that these institutions can be reconfigured as valuable tools for organizing socialist national polities and an anti-imperialist world society. Worth's essay takes exception to Amin's analysis of progressive nationalism as a reversion back to existing national frameworks, and he deploys Rosa Luxemburg's critique of the dangers of 'left nationalism'. Worth contends that any new international should be geared towards new transnational conditions and move beyond the traditional forms and aspirations of twentieth century socialism. Robinson strongly insists on the need for both a transnational analysis and transnational forms of resistance. In contrast, Desai, like Amin, sees the need to emphasize the role played by the state, whether as an arena for progressive reconstruction of the productive economy or as an element in imperialism. She criticizes the past role of Western Marxism and the Western left. Agozino calls for the centrality of race and gender issues and the inclusion of the indigenous peoples of the world in a New International.

Our authors also differ about where, geographically, they see the main contemporary contradictions and the most fertile locations for organizing. Amin is often regarded as a 'Third Worldist', meaning that he saw a primary role for the Global South. He also emphasized the importance of agrarian social relations in the Global South as the main fulcrum of revolution, with small farmers as the key agents of socialist revolution. As the most exploited and oppressed sector of the global system, the small farmers and workers of the Global South would be the most revolutionary agents 
that would challenge and transcend global capitalism by organizing self-reliant national societies. This conviction led to his sometimes taking on quite controversial positions in support of national regimes in the Global South.

Some of the contributors to this Special Forum on Amin's call for a 5th International are globalists, in the sense that they advocate Global North/South coordinated action. However, Michael Tyrala argues that progressive outcomes are more likely to emerge and to have wide consequences if a world party concentrates on the Global North. This position is also implied by Heikki Patomaki's critique of Samir's stance. Patomaki advocates the formation of a world party along the lines of the campaign for democracy within the European Union that has been organized by Diem25. Patomaki also claims that Amin's analysis of global capitalism is stuck in the twentieth century, failing to comprehend the important developments that have emerged more recently. But Carlos Martins presents a clear picture of how Amin adapted Marxian analysis to understand the neoliberal globalization project (Amin, 1997).

Some contributors stress the need to emphasize social and political issues which they argue cannot be excluded. Teivainen questions why the issue of LGBT rights was invisible in Amin's formulation of the foci of the new global instrument he was proposing. Paul Almeida and Leslie Sklair claim that the global environmental catastrophe will be the crucial pivot around which the contemporary progressive movements should and must organize. Valentine Moghadam confronts the difficult problem of the distinction between 'progressive' and 'counterhegemonic,' an important issue that any future global political party of the Left must confront. She sees Jihadist conservatism as part of the Global Right even though it is counterhegemonic.

In concluding this brief introduction, we hope the readers of this Special Forum will explore the many issues implied by Samir Amin's call for a new international. The debate has begun. The form, procedures, and aims of a new international are yet to be determined. This set of contributions is one step closer to the goal. The times are exceptional and the threats to the future health and well being of all humanity are mounting. It is time to seek new forms of unity.

\section{Notes}

1. A 59 minute film with English and French sub-titles about his life and contributions to popular struggles is available at https://mronline.org/2019/03/29/samir-amin-the-organic-intellectual/. Another fulllength video about Samir Amin's life has been made by Aziz Fall. It is titled 'Samir Amin: The Organic Internationalist' (71 minutes, English-French), https://www.youtube.com/watch?v=mKBJNpTU1Jw.

2. The contributors to the Amin/5th forum are mainly from more recent generations of scholar-activists. Samir Amin was part of the generation that came of age before and during the World Revolution of 1968. He and Immanuel Wallerstein, Terence Hopkins, Andre Gunder Frank and Giovanni Arrighi founded and developed the world-system perspective. Except for Wallerstein, that generation has passed along with many others who helped elaborate the prehension of the modern world-system. Gunder Frank passed in 2005, Janet Abu-Lughod in 2013; Walter Goldfrank in 2017, Anibal Quijano, Teotonio dos Santos and Samir Amin in 2018. The contributors to this Special Forum on Amin/5th International are from the second, third and fourth generations (see Table of Contents).

3. Surveys of activists attending the World Social Forums in Porto Alegre (2005) and in Nairobi (2007) found that the attendees were about evenly divided between those who favored the open forum and those who favored a more structured organization (Chase-Dunn, Aldecoa, Breckenridge-Jackson, \& Herrera, 2019).

4. Mamdouh Habashi (habashi.mamdouh@gmail.com) has called for a kickoff meeting of the 5th international proposed by Samir Amin to be held in Nepal in early November of 2019. The title of the meeting is 'Building an alliance of the progressive forces and the oppressed people'. 


\section{Disclosure statement}

No potential conflict of interest was reported by the authors.

\section{Notes on contributors}

Barry Gills is Editor in Chief of Globalizations and Professor of Development Studies at the University of Helsinki. He has written widely on World System theory, neoliberalism, globalization, global crises, democracy, and resistance. He knew the late Samir Amin for a period of some thirty years.

Christopher Chase-Dunn is a Distinguished Professor of Sociology and Director of the Institute for Research on World-Systems at the University of California, Riverside, USA. He is the author of The Spiral of Capitalism and Socialism (with Terry Boswell), Rise and Demise: Comparing World-Systems (with Thomas D. Hall), and Social Change: Globalization from the Stone Age to the Present (with Bruce Lerro). He is the founder and former editor of the Journal of World-Systems Research. Chase-Dunn is currently doing research on transnational social movements. He also studies human sociocultural evolution since the Stone Age and political globalization.

\section{References}

Amin, S. (1980a). Class and nation, historically and in the current crisis. New York, NY: Monthly Review Press. Amin, S. (1980b). The class structure of the contemporary imperialist system. Monthly Review, 31(8), 9-26. Amin, S. (1989). Eurocentrism. New York, NY: Monthly Review Press.

Amin, S. (1990). Delinking: Towards a polycentric world. London: Zed Press.

Amin, S. (1991). The ancient world-systems versus the modern capitalist world-system. Review, 14(3 (Summer)), 349-385.

Amin, S. (1997). Capitalism in the age of globalization. London: Zed Press.

Amin, S. (2008). Towards the fifth international? In Katarina Sehm-Patomaki and Marko Ulvila (Eds.) Global political Paties (pp. 123-143). London: Zed Press.

Chase-Dunn, C., Aldecoa, J., Breckenridge-Jackson, I., \& Herrera, J. (2019). Anarchism in the Web of transnational social movements. Journal of World-Systems Research, 25(2). Retrieved from http://jwsr.pitt.edu/ojs/ index.php/jwsr/index

Democracy in Europe Movement 2025 (Diem25). Retrieved from https://diem25.org/ 